\title{
Usability Analysis of Pornography Detection System on Internet Users using Mc'Calls Method
}

\author{
Bambang Sugiantoro \\ Informatics Engineering Department, Faculty of Science and Technology, UIN Sunan Kalijaga, \\ Jl. Marsda Adisucipto Yogyakarta 55281, Indonesia. \\ Email: bambang.sugiantoro@uin-suka.ac.id
}

\begin{abstract}
Sugiantoro B. 2017. Usability Analysis of Pornography Detection System on Internet Users using Mc'Calls Method. Proc Internat Conf Sci Engin 1: 197-203. At this time there are several tools used to prevent a pornography, the most common one is nawala project that use filtering method in DNS, based on Keyword and Image. This method has a weakness, because it could be wrong, when a researcher or lecturer of science and technology need the information about "sex", the keyword automatically can't be access. Even at this time the maker of pornography sites already so intelligent, they give the sites name which is doesn't have any correlation with pornography. Based on that reason, we proposed a Software quality testing with subject, usability analysis of pornography detection system on internet users using quality factor of Mc Call's which combine the operability and training matrix as a means to determining the quality of software..
\end{abstract}

Keywords: Mc Call's Usability, Operability Matrix, Training matrix, Software Quality

\section{INTRODUCTION}

Software testing is a critical element of software quality assurance and represents a fundamental study of the specification, design, and coding (Pressman, 2002). Software testing is process to identify the accuracy, completeness and quality of the software. For each test need the availability of qualitative measures using strategies by integrating software design test case method into the well-planed steps, and the results is a successfull software construction.

\section{LITERATURE REVIEW}

Software quality is the most important aspect in the development of a software as report by Ariawan (2007) entitled "Penerapan Software Quality Assurace (SQA) Studi kasus Indonesia". Application of Software Quality Assurance are used by all software developers over the Indonesia. This research using web based to collect answer by making online questionnaire. This research use a question with the checklist question of Software Quality Assurance. So, it just analyzing the data by how much according user througout Indonesia which fill the online questionnaire and to validate with offline questionnaire by distributing and direct interviews with users. (Ariawan, 2007) .

The second reference came from the thesis from Universitas Indonesia (Dodick Zulaimi Sudirman,2009) entitled "Penggalian, penerapan, penjaminan kualitas perangkat lunak pada perusahaan perangkat lunak studi kasus Indonesia". This research explored about the quality of software in Indonesia software companies. Then the researchers apllied software quality assurance which is issued by the software company. The Quality
Assurance activities in the software application will determining the results of Software application. The researchers using Daniel Galin Software Quality Shrine Method (Sudirman, 2009).

The third reference owned by (Nur Annisa Tresnasari, 2012). Implementation of quality assurance models that can be applied to small software developers. Research took place in PKSI UIN Sunan Kalijaga Yogyakarta. This research use Software Quality Assurance with the role model of small quality assurance. The result just determining from the process of project development (Tresnasari, 2012).

The reserach was conducted by Aji (2014) from a comparison of the two software, Blackberry Messenger and WhatsApp messenger. The comparison on efficiency factor. The research concluded that the factors of Execution Efficiency is need for improvement and development again, especially on the Blackberryy Messenger Apllication as well as an improvement on operability factor.

Research conducted by testing on two software KeePass Password Safe 1:10 and PDF Split and Merge 2.1.0. Research is done with a focus on testing and Usability Corectness factor. This study describes the results that the software KeePass Password Safe 1:10 Corectness matrix value by $96.2 \%$ and amounted to 77.8\% Usability matrix, while the software PDF Split and Merge 2.1.0 Correctness value of $93.3 \%$ matric and matric Usability amounted to $82.6 \%$. (Hidayati, 2014)

Fararit (2015) conducted research on Sistem Informasi Alumni (Graduates Information System) UIN Sunan Kalijaga. Testing was done with a focus on correctness and usability factor. This research present the result value of the correctness factor at $95.23 \%$, which amounted to $85.71 \%$ completeness, consistency and traceability $100 \%$, while the usability factor is the 
operability at $70.59 \% \pm 16.08 \%$ and training at 149 , $5666 \pm 38.9114$ seconds.

The research was conducted by testing against corectness factors and usability testing on Sistem Informasi Kepegawaian at UIN Sunan Kalijaga Yogyakarta. The results of this study did demonstrate that the matrix completeness in get $100 \%$ result, the matrix operability at $73.66 \% \pm 16.74 \%$, and a training matrix at $45.98 \% \pm 15.23556$ seconds. (Millah, 2015).

Syafirah (2015) tested on Sistem Informasi Surat (Letter Information System) UIN Sunan Kalijaga Yogyakarta. Research conducted by focusing to test the Reliability factors. This research describes the results that the level of reliability the system is owned $85.11 \%$, obtained from calculating the value Accuracy 100\%, $28 \%$ Error Tolerance, Consistency $97.53 \%$, Modularity $100 \%$, and $100 \%$ Simplicity.

Another research conducted by testing the Web Portal System of Pesantren Ibnul Qoyyim Yogyakarta. This research was conducted with focus on testing Usability factor. This research presents the results of a value matrix Operability 11:42 70.51\% $\pm 22 \%$ and matrices Training seconds \pm 17.1 seconds (Utami, 2015)

Yunitasari (2015) tested the E-Learning System UIN Sunan Kalijaga Yogyakarta. This research committed with focus testing on Corectness factors and Usability. This research describes the results that the correctness at $95.23 \%$, which at $85.71 \%$ completeness, consistency and traceability of $100 \%$ to $100 \%$, while the usability factor is the operability at $70.57 \% \pm 16.08 \%$ and training at $149.5666 \pm 38.9114$ seconds.

\section{RESEARCH METHODS}

This research aimed to find out the value of eligibility of pornography detection system by doing the analysis based on standarization of SQA (Software Quality Assurance) and measures parameter that would be analyzed.

The research framework is made to present a complete research designs with a pattern analysis and collection of data used to support this research. Therefore the framework of research is a descriptive research, explaining the part that will be tested. In this case the researchers create a research framework in tabular form in order to facilitate the testing activities in data collection and logging the results of research undertaken.

Descriptive research had a steps in the implementation, including: begins with the the problem, determining the necessary information, describing the data collection procedures, processing the data or information, and draw conclusions from the research undertaken. This stage is also used as a framework in software testing.

\section{Collecting the Data}

The aim of this collection of data was to earn information and facts about the software in the next test then later if the data already collected will be analyzed using the standard quality of McCall. This collection of data can be done with some ways, including:

\section{Study of Literature}

The study of literature is useful as a learning theory to research being undertaken for the researchers because it underlies the testing and analysis that would be implemented. Researchers took from books, journals, theses and articles related to the theme that the researchers take as a basis for analysis and testing. So hopefully will be able to assist researchers on techniques and strategies in conducting research.

\section{System Data}

The System data is taken to be used as a systematic analysis. This system data obtained from whitebox testing using source code modules.

\section{Questionnaries}

This questionnaire was used to collect the data that is then used to calculate the matrix Operability. This questionnaire respondents distributed to users of the system or the respondents at least once using the Pornography detection system. Before distributed, first 's questionnaire will be tested for validity and reliability, after confirmed that the item was valid and reliable, this questionnaire distributed to collecting data.

\section{Method of Calculation}

\section{Correctness}

Correctness matrix, there are three factors which include testing correctness, the matrix was Completeness, Consistency, and Tracebillity. Value correctness in the can by the formula:

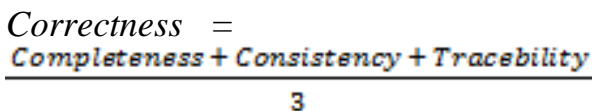

\section{Reliability}

Reliability matrix testing has five factors are: Accuracy, Consistency, Error Tolerance, Modularity, and Simplicity. The percentage value of reliability in the can by the formula:

Reliability $=$ Accuracy+ErrorTolerance+Consistency+Modularity+Simplicity 5

3. Efficiency

Efficiency Matrix has three factors in it, are: Conciseness, Execuition Efficiency and Operability. Value Efficiency in to premises formula:

Efficiency $=$ Conciseness+Execution Efficiency + Openability

3

\section{Integrity}

Integrity Matrix has three factors in it, are: auditability, Instrumentation, and Security. Integrity value in getting to the formula: 
Integrity $=\frac{\text { Auditability+Instrumentation+Security }}{3}$

5. Usability

Usability Matrix has only two factors in it, are: Training and Operability. Usability value in getting to the formula:

$$
\text { Usability }=\frac{\text { Training }+ \text { operability }}{2}
$$

\section{Data Analysis}

The next phase after researchers get the data is analyze the data in accordance with the Mc Call quality standards. Processing and analyzing primary data covering all aspects of product operation by $\mathrm{Mc} \mathrm{Cal}$ quality theory. This analysis was performed on each of the factors that exist to determine the results and seek to conclude whether the system is meeting the quality standards are good in McCall quality theory.

\section{RESULTS AND DISCUSSION}

Porn Detection of Internet Users in the browser by using the theory of McCall's Software Quality Factor. Testing performed with a test parameters by Product Operation McCall includes five matrix: correctness, Reliability, Efficiency, Integrity, and Usability.

\section{Correctness}

Testing the correctness matrix is the extent to which a software meet the specification and the objective mission of users. In correctness matrix testing, there are three factors are: completeness, tracebility and consistency.

\section{Completeness}

Completeness is the extent to wich the full implementation and required functions has been achieved. Here's a summary of the Completeness test result on Pornography detection system:

$$
\begin{aligned}
\text { Completeness } & =\frac{1}{4} \times 100 \% \\
\text { Completeness } & =25 \%
\end{aligned}
$$

From the test results the researchers can be concluded that the pornography detection system has a sufficient value of completeness.

\section{Tracebility}

Tracebility is the ease of implementation or referring back to the program component software user's needs. Here's a summary of results of testing Tracebility factor in pornography detection system that has researchers did.

From the testing Tracebility factor found the researchers had obtained results of testing conducted on 70 menus. A total of remark compatibility between products or systems with documents obtained from the analysis of the test is 70 menus. Here the percentage of Tracebility factors testing:

$$
\begin{aligned}
\text { Tracebility } & =\frac{4}{4} \times 100 \% \\
& =100 \%
\end{aligned}
$$

Based on the results in the get can be concluded that pornography detection system has excellent suitability value between a system with a document analysis.

\section{Consistency}

Consistency is the degree of techniques using a unified design and documentation throughout the software development project. Here's a summary of results of testing Consistency factor.

From the testing the consistency factor that the researchers had obtained results of testing conducted on 4 menus. A total of remark compatibility between systems analysis documents obtained from the test are 4 menus. Here the percentage of Consistency testing factors:

$$
\begin{aligned}
\text { Consistency } & =\frac{4}{4} \times 100 \% \\
& =100 \%
\end{aligned}
$$

These results shows that the pornography detection system has a very good consistency value, between the document analysis system premises.

Based on test results obtained from the third factor, the percentage of correctness end of the test matrix are as follows:

$$
\begin{aligned}
\text { Correctness } & =\frac{\text { Completeness }+ \text { Tracebility }+ \text { Consistency }}{3} \\
& =\frac{25 \%+100 \%+100 \%}{3} \\
& =75 \%
\end{aligned}
$$

It can be concluded that the value of correctness pornography detection system is pretty good.

\section{Reliability}

Testing of reliabilty matrix is the extent to wich software can be expected to carry out its functions with a required precision. In this reliability matrix, there are five testing factors, such as: Accuracy, Consistency, Error tolerance, modularity, and simplicity.

\section{Accuracy}

Accuracy is testing performed to determine the precision of program computation and control. Here's a summary results of accuracy factor testing. From the accuracy factors testing, can be obtained the test conducted on menus. A totla of remark accuracy between input and output obtainde ftrom the test. Here the precentage of accuracy factor testing:

$$
\begin{aligned}
\text { Accuracy } & =\frac{3276}{4010} \times 100 \% \\
& =81.6 \%
\end{aligned}
$$


It can be concluded from the result indicate that accuracy of pornography detection system is good.

\section{Consistency}

The consistency factors testing is same as has ben explores in previous testing of Correctness matrix. And it goes with out spell out again. The resul of Consistency factor testing are:

$$
\begin{aligned}
\text { Consistency } & =\frac{4}{4} \times 100 \% \\
& =100 \%
\end{aligned}
$$

Which shows that pornography detection system has a very good consistency between the documents analyzed by the system.

\section{Error Tolerance}

Error Tolerance is testing performed to determine the value of tolerance for errors in the program. Here's a summary of results of testing Error tolerance factors.

From the Error tolerance testing, here the result of error tolerance testing:

$$
\begin{aligned}
\text { Error Tolerance } & =\frac{734}{4010} \times 100 \% \\
& =18.3 \%
\end{aligned}
$$

These results indicate that the pornography detection system, is still poor in tolerance to errors that place during the use.

\section{Modularity}

Modularity is the testing was conducted to determine the value of how independent or standalone of a module that are components of a software. Testing conducted to determining how independent or the standalone value of a module into a software component. Here's a summary of results of Modularity factors testing.

From the modularity factors testing, can be obtained results that the test carried out of 5 class, the remark total which independent are 2 class, and the dependent class are 3 class. Here the percentage of Modularity factors testing:

$$
\begin{aligned}
\text { Modularity } & =\frac{2}{5} \times 100 \% \\
& =40 \%
\end{aligned}
$$

Based on these results it can be concluded that the pornography detection system module is not good value for its independence.

\section{Simplicity}

Simplicity is the testing of simplicity in the use of source code which refers to how much amount summoned a module which, if greater than or equal to the number of calling a module is the more easily understood (simple). Here's a summary of results of Simplicity factors testing:

Total of class been tested : 5

Remark Simple : : 1

Remark Not Simple $\quad: 4$
From the simplicity factors testing, the results of testing conducted on 56 class, and total class whic is simple is 5 class. Here the percentage of simplicity factors testing :

$$
\begin{aligned}
\text { Simplicity } & =\frac{1}{5} \times 100 \% \\
& =20 \%
\end{aligned}
$$

The test results showed that the level of simplicity of use sourcecode on pornography detection system is still poor.

Based on test results obtained from these five factors, the final percentage of Reliability matrix testing are:

Reliability $=$

Accuracy + Consistency + ErrorTolerance + Modularity + Simplicity

$$
\begin{aligned}
\text { Reliability } & =\frac{81,6 \%+100 \%+18,3+40 \%+20 \%}{5} \\
& =51.98 \%
\end{aligned}
$$

It can be concluded from the results of the research that the reliability values pornography Detection system is still relatively poor, it can be seen from the results of the overall percentage is still below $60 \%$.

\section{Efficiency}

The testing of Efficiency matrix is the amount of computing resources required and source code of a software to perfom its function. In this matrix there are three testing factor such as: Conciseness, Execution Efficiency and Operability.

\section{Conciseness}

Conciseness is the testing with a program calculates conciseness and density in the number of lines of source code. Here's a summary of results of testing Conciseness factors,

$$
\begin{aligned}
& \text { Total of Class been tested : } 5 \\
& \text { Total value of remark class } \quad: 0.1894
\end{aligned}
$$

From the Conciseness factors testing the results for being tested at 56 class, and the total value of remark class discovered is 1188.97 . Here the percentage of the testing for Conciseness factors:

$$
\begin{aligned}
\text { Conciseness } & =\frac{5-0,1894}{5} \times 100 \% \\
& =62.12 \%
\end{aligned}
$$

Based on the percentage of these tests indicate that the average density of lines of code is $62.12 \%$.

\section{Execution Efficiency}

Execution Efficiency is the testing by calculating the efficiency of the program run-time performance when used on the device. Calculation of the run-time performance was include memory used when already installed, until the user memory (RAM) when the 
program runs. The following estimates for Conciseness factors in Mozilla Firefox:

\section{Execution Efficiency $=90 \%$}

\section{Operability}

Operability is the testing of the ease of the user/ operator of the program. In stage operability using a questionnaire given to the users of the system or at least people who have used the system. Collecting data on the user's overall questionnaire provide an assessment of pornography detection system. Here are results of testing Operability factors

The following approximate percentage for Operability factors:

\section{Operability $=80 \%$}

The conclusion of these tests is that the value of user satisfaction against pornography detection system is $80 \%$, which means that a good level of user satisfaction. Based on test results obtained from the third factor, the final percentage of Efficiency matrix are:

\section{Efficiency $=$}

Conciseness + Execution Efficiency + Operability 3

Efficiency $=\frac{62.12 \%+90 \%+80 \%}{3}$

Efficiency $=77.3 \%$

These results indicate that the level of efficiency pornography detection system as a whole has been very good and the level of user satisfaction is also very good system.

\section{Integrity}

Integrity is a test of the extent to which access to software and data by unauthorized parties can be controlled. In the integrity matrix testing there are three testing factors, include: auditability, Instrumentation, and Security.

\section{Auditability}

Auditability are adjustments to a standard that can be checked. Auditability is the testing software by looking at designs the system.

The following approximate percentage for auditability factors:

\section{Auditability $=100 \%$}

It can be concluded that the pornography detection system have compatibility between systems with document analysis.

\section{Instrumentation}

Instrumentation is the extent to which surveillance program has its own operations and identify errors happened. So that the program can recognize, identify and handle errors happened. Here are estimates Instrumentation factors.
Here the percentage of the testing for Instrumentation factors:

$$
\text { Instrumentation }=90 \%
$$

It can be concluded that pornography detection systems have clear limits or a good instrument.

\section{Security}

Security is a mechanism that controls the availability or protect programs or data. Here are the results of security factors testing.

Table 1. Result of security factor testing.

\begin{tabular}{clcccc}
\hline No & Activity & $\begin{array}{c}\text { Doc } \\
\text { Analysis }\end{array}$ & Product & Remark & Note \\
\hline \hline 1. & Login & $x$ & $x$ & $x$ \\
2. & Session & $x$ & $x$ & $x$ & \\
2ogout & Level User & $x$ & $x$ & $\times$ \\
4. & Enkripsi & $x$ & $x$ & $x$ \\
& Password & & Total & 0 \\
\hline
\end{tabular}

From the security factors test that obtained results the testing conducted on 5 items system security. A total of remark obtained from the testing are 3 menus contained in pornography detection system. Here the percentage of the testing for Security factors:

$$
\begin{aligned}
\text { Security } & =\frac{0}{4} \times 100 \% \\
& =0 \%
\end{aligned}
$$

The researchers concluded that pornography detection system has a very poor safety standards Based on the testing that was done above, the percentage of total Integrity matrix get is:

$$
\begin{aligned}
\text { Integrity } & =\frac{\text { Auditability }+ \text { Instrumentation }+ \text { Security }}{3} \\
\text { Integrity } & =\frac{100 \%+90 \%+0 \%}{3} \\
\text { Integrity } & =63.3 \%
\end{aligned}
$$

The results of these tests show that the relationship between the system and security of the detection system pornography, has been good.

\section{Usability}

The usability matrix testing is the effort required to learn, operate, prepare input and interpret the outpit of software. In the test, there are two testing factors are operability and training.

\section{Operability}

Operability is the testing of the ease of use of the program.Operability testing has been discussed in the Efficiency matrix and has been describe in the efficiency matrix wich the value isi $80 \%$ 
Based on these results the researchers concluded that the level of satisfaction buffer users against pornography detection system is located at a good rate.

\section{Training}

Training is the extent to which software to help implement the new system by the user. From the training factors, respondents were asked to try the 6 activity in pornography detection system then each of these activities in the record time of use. The following estimates for training factor testing:

$$
\text { Training }=170,96 \text { seconds }
$$

Based on the assumption of this test indicate that the user takes about \pm 3 minutes to understand the pornography detection system.

\section{Research Final Results}

At this stage of research will be presented the result of research that has been done. Based on Produc Operation parameter which in McCall quality theory, there are five matrix with six factors which have all testing and analysis. Researcher have an assumotion from pornography detection system data. Here is the final result of this research.

\section{Correctness}

Based on the above test results showed that the value of correctness on pornography detection system at: $75 \%$. Results obtained from the calculation of the three factors contained in the Corectness matrix, are: Completeness at $25 \%$, Tracebility was $100 \%$ and Consistency at $100 \%$. From these results it can be concluded that pornography detection system has a value of correctness is good enough.

\section{Reliability}

Based on the results of testing that has been done, the results obtained Reliability matrix is: $51.98 \%$. Those results can be accumulated from the five factors contained in the matrix of Reliability, including: Accuracy amounting to $81.6 \%$, amounting to $100 \%$ Consistency, Error Tolerance at $18.3 \%$, Modularity at $40 \%$, and Simplicity at $20 \%$. These results show that the reliability matrix values obtained are still relatively low.

The results of the reliability matrix test is low because it based on testing that researchers do validation on the fields in the three tested menu is still very low, caused the lower value of error tolerance factor. While for modularity and simplicity factor inferior results.

\section{Efficiency}

The results obtained from the efficiency matrix testing on pornography detection system is as follows: $77.3 \%$. The results of the get from the accumulation of the three factors in the Efficiency, which is: Conciseness $62.12 \%$, Execution Efficiency by $90 \%$, and Operability by $80 \%$. On Efficiency matrix value already showed that they got very good value.

\section{Integrity}

Based on the testing that was done above, the result obtained on Integrity matrix is: $63.3 \%$. Obtained from third accumulation factor, which is: auditability at $100 \%$, Instrumentation at $90 \%$, and Security at $0 \%$. From these results it can be concluded that the system has had a good relation, but very poor on the security factor.

\section{CONCLUSION}

Based on the research, it is concluded that the McCall method can be applied to the measurement of software quality detection system of pornography on the Internet user's. Overall the system's detection of pornography Internet users have good quality based on the theory of McCall quality. From the McCall quality testing based on the theory that the best quality is the Usability matrix with a yield at $80 \%$ and the worst is the matrix of Reliability with a yield at $51.98 \%$.

\section{ACKNOWLEDGEMENT}

Lembaga Penelitian dan Pengabdian kepada Masyarakat UIN Sunan Kalijaga Yogykarta.

\section{REFERENCES}

(2010). Sejarah SLiMS. Access from http://slims.web.id/web/?q=node/70 date 8 Oktober 2015. (2012). Deteksi pornografi Pengguna Internet di browser (SLiMS). Accsess from http://perpustakaan.kemdikbud.go.id/perpus/?page_id=224 pada tanggal 8 Oktober 2015.

Aji, D. M. (2014). Analisis Komparatif Faktor Efisiensi Pada Aplikasi Blackberry Messenger Berbasis Android Dengan Whatsapp Messenger Berbasis Android Berdasarkan Teori McCall's Quality Factors. Yogyakarta: Skripsi Teknik Informatika, UIN Sunan Kalijaga.

Ardli, I. Z. (2015). Analisis Sistem Informasi Keuanga Desa di Kecamatan Wonosari Klaten Berdasarkan teori Kualitas McCall. Yogyakarta: Skripsi Teknik Informatika, UIN Sunan Kalijaga.

Ariawan, Y. (2007). Penerapan Software Quality Assurance. Jakarta: UI Press.

Arikunto, S. (2002). Metodologi Penelitian. Jakarta: PT Rineka Cipta.

Fararit, F. M. (2015). Pengujian Faktor Corectness dan Usability Sistem Informasi Alumni UIN Sunan Kalijaga Yogyakarta Menggunakan Metode McCall. Yogyakarta: Skripsi Teknik Informatika, UIN Sunan Kalijaga.

Gunawan, T. (2015). Pengujian Perangkat Lunak Deteksi pornografi Pengguna Internet di browser Menggunakan Metode McCall. Yogyakarta: Skripsi Teknik Informatika, UIN Sunan Kalijaga.

Hidayati, A. M. (2014). Verifikasi dan Validasi Kerangka Kerja Pengujian Perangkat Lunak Berbasis McCall's Software Quality Checklist. Yogyakarta: Skripsi Teknik Informatika, UIN Sunan Kalijaga.

IEEE. (1990). Standard Glosary of Software Engineering Technology. 
Millah, N. (2015). Pengujian Faktor Correctness Dan Usability Sistem Informasi Kepegawaian UIN Sunan Kalijaga Yogyakarta Menggunakan Metode MCCALL. Yogyakarta: Skripsi Teknik Informatika, UIN Sunan Kalijaga.

Myers, G. J. (1979). The Art of Software Testing. Willey.

Notoatmodjo, S. (2005). Metode Penelitian Kesehatan. Jakarta: PT Rineka Cipta.

Nuryanto, A. (2014). Analisis Pengujian Faktor Reliability Sistem Informasi Akademik UIN Sunan Kalijaga Menggunakan Metode Mccall. Yogyakarta: Skripsi Teknik Informatika, UIN Sunan Kalijaga.

Pressman, R. S. (2005). Software Engineering A Practicioner's Approach. Amerika Serikat: Mc Graw Hill.

Rofi'ah, H. (2015). Analisis Pengujian Faktor Reability Sistem Informasi Akademik STMIK El Rahma Yogyakarta Menggunakan Metode MCCALL. Yogyakarta: Skripsi Teknik Informatika, UIN Sunan Kalijaga.

Santosa, P. B. (2005). Analisis Statistik dengan Microsoft Excel dan SPSS. Yogyakarta: Andi.

Septiani, S. (2015). Analisis Usablity Sistem Perpustakaan Kota Yogyakarta Menggunakan Metode MCCALL. Yogyakarta: Skripsi Teknik Informatika, UIN Sunan Kalijaga.
Syafirah, N. E. (2015). Pengujian Faktor Reliability Sistem Informasi Surat UIN Sunan Kalijaga Dengan Menggunakan Teori Mccall. Yogyakarta: Skripsi Teknik Informatika, UIN Sunan Kalijaga.

Utami, P. S. (2015). Analisis Faktor Usabilitas Pada Sistem Informasi Portan Web Pondok Pesantren Ibnul Qoyyim Yogyakarta Berdasarkan McCal's Quality Factor. Yogyakarta: Skripsi Teknik Informatika, UIN Sunan Kalijaga.

Wardani, D. O. (2014). Analisis Perangkat Lunak Opengov Paperless Government Collaboration Suite Pada Pemerintahan Daerah Purbalingga Berdasarkan Teori Kualitas Mccall's. Yogyakarta: Skripsi Teknik Informatika, UIN Sunan Kalijaga.

Yunitasari, Y. (2015). Pengujian Faktor Correctness Dan Usability Sistem E-learning UIN Sunan Kalijaga Yogyakarta Berdasarkan Metode Mccall. Yogyakarta: Skripsi Teknik Informatika, UIN Sunan Kalijaga.

Zakiyah, K. (2015). Analisis Faktor Efisiensi Dan Usabilitas Pada Sistem Admisi UIN Sunan Kalijaga Yogyakarta Berdasarkan Teori Kualitas MCCALL. Yogyakarta: Skripsi Telnik Informatika, UIN Sunan Kalijaga. 
THIS PAGE INTENTIONALLY LEFT BLANK 